\title{
Survey on crop varieties and agricultural practise of Karnataka
}

Shahi p. Ismail ${ }^{1 *}$ and Dr. U. Sivagamasundari. ${ }^{2}$

Department of Life Sciences Kristu Jayanti College (Autonomous), Bangalore, Karnataka

Corresponding Author*: shahicool261997@gmail.com

\begin{abstract}
Abstrac
Pursuing agriculture plays a very important role in the Indian economy. It is the backbone of our country. $70 \%$ of the population depends on agriculture for food and money. It is the major profession in the rural areas. The cultivation procedure mainly depends on climatic conditions and nature of soil parameters. Sustainable agronomy uses crops and its varieties that are better adapted to ecologically based production practices than those currently available, which bred for high-input agriculture. This survey exclusively shares the recent times of agricultural practices being used from 90's till date in the $21^{\text {st }}$ Century. We have investigated about 25 different varieties of crops from 7 different regions from the state of Karnataka. The widespread surveys have shown different parameters to ensure the geographical area, flora \& fauna and other crop parameters in traditional practice. For instance, in this era more of commercially and ready-to-use practices are followed more than the manual or man-made. There is always a negative side for the positive outcome even in agricultural sectors. Even plants are considered to be humans that live on its shelter and depend on food.
\end{abstract}

Keywords: Agriculture, flora, fauna

\section{Introduction}

Every state is known for its unique agricultural produce. Agriculture is one the most important and key for the economy People in Karnataka mostly come from agricultural background and passing on to their generations. Rural part of Karnataka are the main sectors for the farming and that they have good agricultural practices. (Patil, 2009; Mondal, 2011). Though the people of the rural places are not well educated they still have an idea in and around the methods of the farming. They use the traditional method for growing sowing and harvesting of the crops. Agriculture for them is the livelihood, shelter, food and source of living.

The crops in Karnataka mainly grows in 3 different climatic conditions (Ravindrababu et al., 2010): KharifApril-September Rabi- October- December; Summer season- January to March. (Reddy, 1982; Nagarjun and Radder, 1983). There are different types of crops that are growing in Karnataka such as commercial crops, food crops, horticultural crops, floricultural, oilseed crops and plantation crops. It includes corn, coffee, maize, paddy, sugarcane, banana, sunflower, mustard etc. The survey was done in seven different regions of east Karnataka (rural-village). The 7 different regions had different climatic condition, with different growth parameters and the soil in which the crops grow. (Toole et al., 1964), (Venkatesh et al., 2016). The survey was done on 25 different varieties of crops for the understanding of their growth, life and the conditions. In some crops the diseases were observed like maize, bitter leaf, mustard etc. (Karthikeyan et al., 2009; Abdel-Monaim et al., 2011). The survey was done during the day time and the application used here are geo tag and geo earth for the location purposes and to identify the longitude and latitude of the geographical locations.

\section{Materials and Methods}

The materials used in the survey was questionnaires for the information purposes, a measuring tape and Mobile application for the detection of location: Geo tag \& Geo earth. The survey was conducted with the help of the consent of the farmers in their land and the knowledge. The method used in analysing the crops was done using geo tag for the detection of geographical location with longitude and latitude of all the 7 regions of Karnataka.

The regions taken for the survey includes (1) Chikka Gubbi (2) Dodda Gubbi (3) Kalkeri (4) Channasandra (5) Rampura village (6) Hoskote (7) TC Palaya regions of east Karnataka. The crops were identified with the help of the farmers in their local language and common names and expressing it out in the scientific manner.

All the 25 crop varieties of the above 7 regions were taken for the measurement of its height, leaf size, distance between the plants planted, number of leaves in each plant with the number of fruits. Application of pesticides and organic manure was spotted on leaves and type of soil also noted as observation parameters. Virtual observations of different crop fields and the vocal information collected from the agricultural practice of farmers in villages visited enable to understand better about the crops planted, mode of irrigation mechanism with disease management measurement in relevant climatic conditions

\section{Results and discussion}

\section{Cropping Pattern}


Vol. 15 (5) 519-523, ISSN 0973-8916 (Print), 2230-7303 (Online)

10.5530/ctbp.2021.3s.49

Table: 1 Virtually surveyed vegetative parameters of 25 crop varieties in seven different regions of Karnataka

\begin{tabular}{|c|c|c|c|c|c|c|c|c|c|c|}
\hline Sl. No. & Field Location & $\begin{array}{c}\text { Vernacular } \\
\text { Name }\end{array}$ & Scientific Name & $\begin{array}{l}\text { Type of } \\
\text { soil }\end{array}$ & \begin{tabular}{|l} 
Pesticide \\
\end{tabular} & $\begin{array}{l}\text { Leaf } \\
\text { Size }\end{array}$ & \begin{tabular}{|l|} 
No. of \\
Leaves
\end{tabular} & $\begin{array}{l}\text { No. of } \\
\text { fruits }\end{array}$ & $\begin{array}{c}\text { Plant } \\
\text { Height }\end{array}$ & $\begin{array}{c}\text { Distance } \\
\text { between } \\
\text { plants }\end{array}$ \\
\hline 1(A) & Rampura Road & Palak & Spinacia oleracea & Red & $\begin{array}{l}\text { Coragen, } \\
\text { Kem- } 45\end{array}$ & $3 \mathrm{~cm}$ & 4 & ---------- & $10 "-1 \mathrm{ft}$ & 8 " inch \\
\hline 2 & Rampura Road & $\begin{array}{l}\text { Pumpkin, } \\
\text { Kaddu }\end{array}$ & Cucurbita & Dry & Mancoze B & $9 \mathrm{~cm}$ & $2-3$ & $1 /$ crop & $12 \mathrm{~cm}$ & $4 " \mathrm{ft}$ \\
\hline 3 & Rampura Road & Guva, Peru & Psidium guajava & Red & Karaban-50 & $5.6 \mathrm{~cm}$ & $5-6$ & $2-3$ & $15 \mathrm{ft}$ & $8 " \mathrm{ft}$ \\
\hline 4 & Rampura Road & $\begin{array}{l}\text { Orange, } \\
\text { Santra }\end{array}$ & Citrus sinensis & Red & Chlorpyrifos & $3.5 \mathrm{~cm}$ & 8/branch & 1/leaf & $20 \mathrm{ft}$ & $4-6 " \mathrm{ft}$ \\
\hline 5 & Rampura Road & Fig, Anjeer & Ficus carica & Dry Red & Sulfur Spray & $5 \mathrm{~cm}$ & 5/branch & $\begin{array}{l}\text { No } \\
\text { season }\end{array}$ & $20-25 \mathrm{ft}$ & $5 " \mathrm{ft}$ \\
\hline 6 & Rampura Road & $\begin{array}{l}\text { Banana, } \\
\text { Kela, Pazham }\end{array}$ & Musa balbisiana & Dry Red & $\begin{array}{l}\text { Chlorpyrifos } \\
\text { Carbyl }\end{array}$ & $44 \mathrm{~cm}$ & 1 & $\begin{array}{l}4- \\
6 / \text { branch }\end{array}$ & $15-20 \mathrm{ft}$ & $60 \mathrm{~cm}$ \\
\hline 7 & Rampura Road & Carambola & $\begin{array}{l}\text { Averrhoa } \\
\text { carambola }\end{array}$ & Dry Red & $\begin{array}{l}\text { Oraganocide } \\
\text { Graden Spray }\end{array}$ & $3.2 \mathrm{~cm}$ & $\begin{array}{l}20 / \text { branc } \\
\text { h }\end{array}$ & 2/leaf & $20-25 \mathrm{ft}$ & $10 \mathrm{ft}$ \\
\hline 8 & Rampura Road & Coffee & Coffea arabica & Dry Red & $\begin{array}{l}\text { Cypermetrin } \\
\text { Deltametrin }\end{array}$ & $7 \mathrm{~cm}$ & $\begin{array}{l}20 / \text { branc } \\
\text { h }\end{array}$ & $5-6$ & $20-24 \mathrm{ft}$ & $4 " \mathrm{ft}$ \\
\hline 9 & Rampura Road & Rose Apple & Syzygium aqueum & Dry Red & $\begin{array}{l}\text { Neem oil, } \\
\text { Insecticidal } \\
\text { Soap }\end{array}$ & $6.5 \mathrm{~cm}$ & 10 & $5 /$ branch & $25-30 \mathrm{ft}$ & $6 " \mathrm{ft}$ \\
\hline 10(B) & Hoskote & Bitter Gourd & $\begin{array}{l}\text { Momordica } \\
\text { charantia }\end{array}$ & Red & $\begin{array}{l}\text { Permethrin } \\
\text { Deltametrin }\end{array}$ & $2 \mathrm{~cm}$ & 20 & $\begin{array}{l}5- \\
6 / \text { branch }\end{array}$ & $70 \mathrm{~cm}$ & $22 \mathrm{~cm}$ \\
\hline 11 & Hoskote & Chilli & Capsicum frutesens & Red & $\begin{array}{l}\text { Combination } \\
\text { of crushed } \\
\text { garlic } \\
\text { and chilli po } \\
\text { wder with } \\
\text { one } \\
\text { tablespoon of } \\
\text { vegetable oil } \\
+ \text { soap liquid } \\
\end{array}$ & $1.5 \mathrm{~cm}$ & $6-7$ & $\begin{array}{l}15- \\
20 / \text { branc } \\
\text { h }\end{array}$ & $20 \mathrm{~cm}$ & $2 \mathrm{~cm}$ \\
\hline 12 & Hoskote & Papaya & Carica papaya & Dry Red & $\begin{array}{l}\text { Combination } \\
\text { of Immuno } \\
+ \text { Enviro+ } \\
\text { Cyto Plus. }\end{array}$ & $5.2 \mathrm{~cm}$ & $20-30$ & 20/plant & $12 \mathrm{ft}$ & 5" FT \\
\hline 13 & Hoskote & Chikku & Manilkara zapota & Red & $\begin{array}{l}\text { Profenophos } \\
\text { Cypermetrin }\end{array}$ & $4 \mathrm{~cm}$ & 8 & 6/branch & $15-20 \mathrm{ft}$ & 4" FT \\
\hline 14 & Channasandra & Malabar Nuts & Justicia adhatoda & Black & No Spray & $4 \mathrm{~cm}$ & $6-10$ & ------ & $12 \mathrm{ft}$ & $2 \mathrm{ft}$ \\
\hline 15 & Channasandra & Lemon & Citrus medica & Red & $\begin{array}{l}\text { Neem oil, } \\
\text { Insecticidal } \\
\text { Soap }\end{array}$ & $3.5 \mathrm{~cm}$ & $5-6$ & 1/leaf & $2 \mathrm{ft}$ & $2 \mathrm{ft}$ \\
\hline 16 & Channasandra & Grape & Vitis $s p$. & Red & $\begin{array}{l}\text { Carbyl, } \\
\text { permethrin } \\
\text { Spinosad }\end{array}$ & $5 \mathrm{~cm}$ & 10 & Bunch & $60 \mathrm{~cm}$ & $2 \mathrm{ft}$ \\
\hline 17(D) & Kalkeri & Gotukula & Bacopa monnieri & Dry Red & $\begin{array}{l}\text { Permethrin } \\
\text { Deltametrin }\end{array}$ & $1.5 \mathrm{~cm}$ & 10 & -------- & $0.5 \mathrm{ft}$ & $30 \mathrm{~cm}$ \\
\hline $18(\mathrm{E})$ & Chikka Gubbi & Marigold & $\begin{array}{l}\text { Chrysanthemum } \\
\text { morifolium }\end{array}$ & Dry Red & Pyrethroids & $2 \mathrm{~cm}$ & $6-8$ & ------- & $1 \mathrm{ft}$ & $18 \mathrm{~cm}$ \\
\hline 19 & Chikka Gubbi & Corn & Zea mays & Dry Red & \begin{tabular}{|l} 
Atrazin \\
Glyphospahte \\
Mixture \\
\end{tabular} & $33 \mathrm{~cm}$ & $3-4$ & $2-3$ & $60 \mathrm{~cm}$ & $21 \mathrm{~cm}$ \\
\hline 20 & Chikka Gubbi & Musturd & Brassica nigra & Dry Red & $\begin{array}{l}\text { Organic } \\
\text { Sucking pest } \\
\text { Controller } \\
\text { Liquid } \\
\end{array}$ & $1 \mathrm{~cm}$ & $10-15$ & ----- & $5.8 \mathrm{ft}$ & $5 \mathrm{~cm}$ \\
\hline 21 & Chikka Gubbi & Copper Leaf & $\begin{array}{l}\text { Acalypha } \\
\text { wilkesiana }\end{array}$ & Dry Red & \begin{tabular}{|l|} 
Copper \\
Fungicide \\
\end{tabular} & $3 \mathrm{~cm}$ & $12-15$ & $\begin{array}{l}----- \\
\end{array}$ & $2 \mathrm{~m}$ & $2 \mathrm{ft}$ \\
\hline $22(\mathbf{F})$ & Dodda Gubbi & $\begin{array}{l}\text { Monkey } \\
\text { Grass }\end{array}$ & $\begin{array}{l}\text { Ophiopogon } \\
\text { japonicus }\end{array}$ & Dry Red & Neem oil & $15 \mathrm{~cm}$ & 20 & ------ & $1 \mathrm{~m}$ & $20 \mathrm{~cm}$ \\
\hline 23 & Dodda Gubbi & Sarpagandha & $\begin{array}{l}\text { Rauwolfia } \\
\text { serpentina }\end{array}$ & Dry Red & \begin{tabular}{|l|} 
Neem, \\
Pyrethrin \\
\end{tabular} & $2 \mathrm{~cm}$ & 10 & 2/branch & $2 \mathrm{ft}$ & $2 \mathrm{ft}$ \\
\hline $24(\mathrm{G})$ & T.C Palaya & $\begin{array}{l}\text { Garden } \\
\text { Croton }\end{array}$ & $\begin{array}{l}\text { Codiaeum } \\
\text { variegatum }\end{array}$ & Dry Red & Neem oil & $15 \mathrm{~cm}$ & $5-7$ & 10 & $2 \mathrm{~m}$ & $1 \mathrm{ft}$ \\
\hline 25 & T.C Palaya & Bitter Leaf & $\begin{array}{l}\text { Veronica } \\
\text { amygdalina }\end{array}$ & Dry Red & \begin{tabular}{|l} 
Neem, \\
Pyrethrin
\end{tabular} & $30 \mathrm{~cm}$ & $7-8$ & 1/branch & $4 \mathrm{ft}$ & $1 \mathrm{~m}$ \\
\hline
\end{tabular}

The above table shows that the most used soil is Dry red soil or red soil in which the crops are growing and this soil is favourable in all the climatic conditions and giving proper nutrients and nourishments to the plants. The pesticides are occasionally used for the plants because the crops grown in all the above 7 regions are protected from unwanted pests and weeds and therefore the crops are grown at the best without the use of much pesticides. 
Table: 2 Climatic conditions and agricultural practices of 25 crop varieties in seven different regions of Karnataka

\begin{tabular}{|c|c|c|c|c|c|}
\hline SL.No. & $\begin{array}{l}\text { Vernacular } \\
\text { Name }\end{array}$ & Season & Weather & Manure Used & $\begin{array}{c}\text { Irrigation } \\
\text { method }\end{array}$ \\
\hline 1 & Palak & Spring, late winter, late summer & $\begin{array}{l}\text { Cold weather, shady } \\
\text { climate }\end{array}$ & Cow dung & Drip \\
\hline 2 & Pumpkin, Kaddu & December- January (or) June - July & Warm climate & Cow dung & Drip \\
\hline 3 & Guva, Peru & July-September & Cold climate & Cow dung & Drip \\
\hline 4 & Orange, Santra & July to September & Moderate & Cow dung & Drip \\
\hline 5 & Fig, Anjeer & Summer season (February - March) & Hot climate & Cow dung & Drip \\
\hline 6 & $\begin{array}{ll}\text { Banana, } \\
\text { Pazham }\end{array}$ & Any season & Humid and dry & Waste vegetables, cow dung & Drip \\
\hline 7 & Carambola & $\begin{array}{l}\text { September-October January- } \\
\text { February }\end{array}$ & Warm, moist climate & Organic waste & Drip \\
\hline 8 & Coffee & November to January & $\begin{array}{l}\text { Hot and } \\
\text { humid climate }\end{array}$ & Cow dung & Drip \\
\hline 9 & Rose Apple & June to September & Cool climate & Cow dung & Drip \\
\hline 10 & Bitter Gourd & January to March, June-July & $\begin{array}{l}\text { hot and } \\
\text { humid climates. }\end{array}$ & Waste materials from kitchen \& cow dung & Sprinkler \\
\hline 11 & Chilli & $\begin{array}{l}\text { January-February; September- } \\
\text { October }\end{array}$ & Moderate & Waste materials from kitchen \& cow dung & Sprinkler \\
\hline 12 & Papaya & Throughout the year & Very hot climate & Waste materials from kitchen \& cow dung & Sprinkler \\
\hline 13 & Chikku & Throughout the year & Moderate climate & Waste materials from kitchen \& cow dung & Sprinkler \\
\hline 14 & Malabar Nuts & June-July & Hot climate & Goat pellets and cow dung & Sprinkler \\
\hline 15 & Lemon & December- March & Moderate & Goat pellets and cow dung & Sprinkler \\
\hline 16 & Grape & $\begin{array}{l}\text { April to September, October to } \\
\text { March }\end{array}$ & Hot \& dry period & Organic waste, Goat pellets and cow dung & Drip \\
\hline 17 & Gotukula & November- January & Humid \& warm & Cow dung & Drip \\
\hline 18 & Marigold & November- January & Moderate & Goat pellets and cow dung & $\begin{array}{l}\text { Sprinkler } \\
\text { \& drip }\end{array}$ \\
\hline 19 & Corn & April- May & Warm and sunny & Cow dung, Waste vegetables & $\begin{array}{l}\text { Sprinkler } \\
\text { \& drip }\end{array}$ \\
\hline 20 & Musturd & $\begin{array}{l}\text { September-October, February- } \\
\text { March. }\end{array}$ & Cool \& dry climate & Cow dung, Waste vegetables & $\begin{array}{l}\text { Sprinkler } \\
\text { \& drip }\end{array}$ \\
\hline 21 & Copper Leaf & November- January & $\begin{array}{l}\text { Cool and sunny } \\
\text { season }\end{array}$ & Cow dung, Waste vegetables & $\begin{array}{l}\text { Sprinkler } \\
\text { \& drip }\end{array}$ \\
\hline 22 & Monkey Grass & June- August & Cool climate & Cow dung, Waste vegetables & $\begin{array}{l}\text { Sprinkler } \\
\text { \& drip }\end{array}$ \\
\hline 23 & Sarpagandha & October- January & Cool climate & Cow dung, Waste vegetables & $\begin{array}{l}\text { Sprinkler } \\
\text { \& drip }\end{array}$ \\
\hline 24 & Garden Croton & Throughout the season & Moderate climate & Cow dung, Waste vegetables & $\begin{array}{l}\text { Sprinkler } \\
\& \text { drip }\end{array}$ \\
\hline 25 & Bitter Leaf & April- May, June- July & Hot climate & Cow dung, Waste vegetables & $\begin{array}{l}\text { Sprinkler } \\
\text { \& drip }\end{array}$ \\
\hline
\end{tabular}

The above crop varieties grow in different season in their favourable climate. The use of manure here are the cow dungs and waste vegetables which has been practiced since ages for the agricultural practices. Cow dung has lot of potentials for the growth of the crops. Irrigation method used in all the crops are combination of drip and sprinkler irrigation methods that helps and support the plants.

Table: 3 Insects and plant disease observed in field crops

\begin{tabular}{|c|l|c|c|}
\hline S.No. & Plant Name & Insects in Particular Plants & Plant disease \\
\hline 1 & Palak & Cutworm, Aphid & Downy, mildew, Fusarium will \\
\hline 2 & Pumpkin, Kaddu & Beetles & Powdery mildew \\
\hline 3 & Guva, Peru & Fruit fly, mealybugs & Citrus canker \\
\hline 4 & Orange, Santra & Leaf miner, whitefly & Fig mosaic virus, brown rot \\
\hline 5 & Fig, Anjeer & wasp & banana wilt \\
\hline 6 & Banana, Kela, & Mealybugs, red spider, aphids & Anthracnose, sooty mould \\
\hline 7 & Carambola & Mites, caterpillar & \\
\hline
\end{tabular}




\begin{tabular}{|c|c|c|c|}
\hline 8 & Coffee & Mealybugs & Coffee rot, Hemileia vastatrix \\
\hline 9 & Rose Apple & Aphids, Scales & Not Known \\
\hline 10 & Bitter Gourd & Melon fruit fly & Bitter gourd yellow mosaic virus \\
\hline 11 & Chilli & Aphids, whitefly & Mosaic leaf, powdery mildew \\
\hline 12 & Papaya & Aphids, whitefly & Papaya mosaic disease \\
\hline 13 & Chikku & Caterpiller & Leaf spot, sooty mould \\
\hline 14 & Malabar Nuts & - & Rhizoctonia solani \\
\hline 15 & Lemon & Citrus butterfly, whitefly & lemon scab, brown rot \\
\hline 16 & Grape & Berry moth & Botrytis, downy mildew \\
\hline 17 & Gotukula & Red spider mites & Not Known \\
\hline 18 & Marigold & Aphids & Smuts \\
\hline 19 & Corn & Corn earworms & Eye spot, southern rust \\
\hline 20 & Musturd & Aphids & Damping-off, \\
\hline 21 & Copper Leaf & Mealybugs & Not Known \\
\hline 22 & Monkey Grass & Beetles & Not Known \\
\hline 23 & Sarpagandha & Scale, citrus black fly & Leaf spot disease \\
\hline 24 & Garden Croton & Mealybugs, Scales & Powdery Mildew, Crown Gall \\
\hline 25 & Bitter Leaf & Mealybugs, Scales & Not Known \\
\hline
\end{tabular}

The plant diseases and insects vary from crops to crops. Each insect plays a role in their particular plant habitat. The plant diseases caused due to many parameters like the spotting of the whole plants or any part of the plants, it can also happen to the disease-causing insects/ birds/animals/pesticides etc. There are few crops whose diseases are not known or studied till date such as Garden croton, monkey grass, bitter leaf etc.

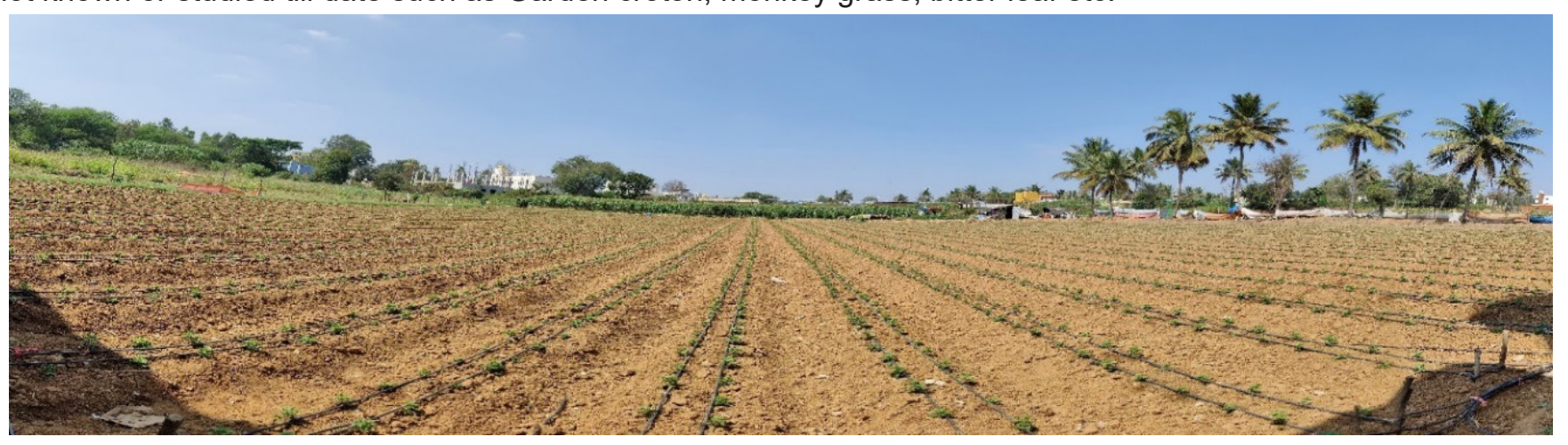

Fig: 1 Field view of chrysanthemum - Chikka Gubbi, Karnataka

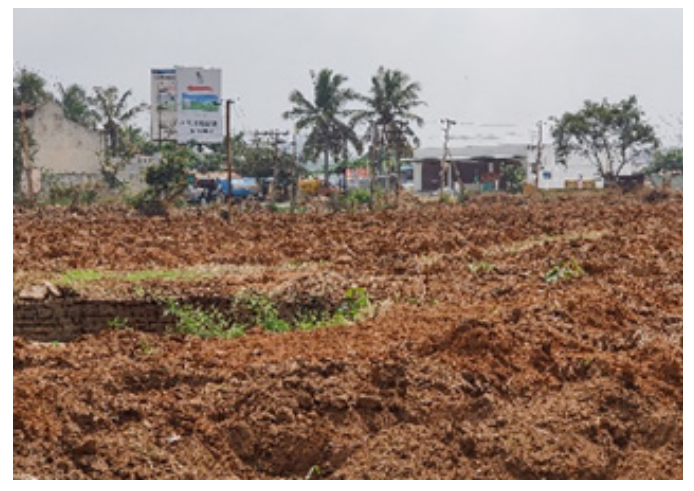

Fig: 2 Red Soil field - Channasandra, Karnataka

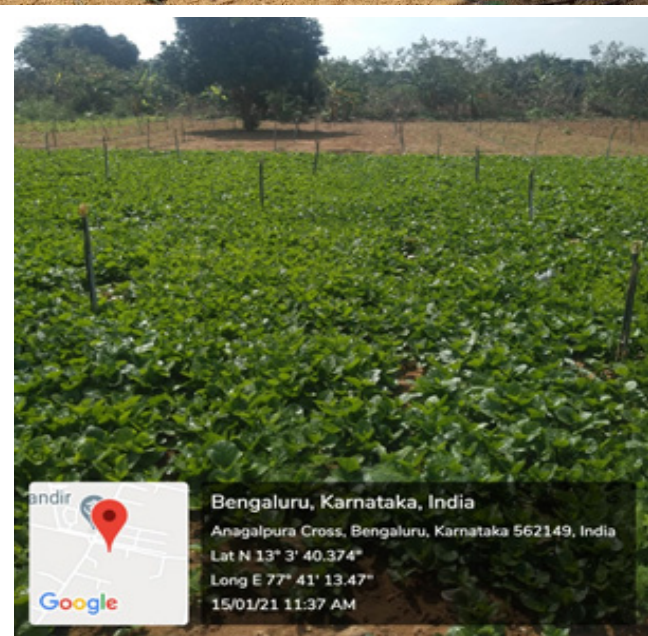

Fig: 3 Palak field - Ramapura, Karnataka 
- The cropping pattern of the region is influenced not only by agro-climatic conditions like rainfall, soil, temperature, but also by government policies and programmes for crop production in the form of subsidies, support prices, tariffs and speed of infrastructure development.

- The overall trends in area allotted for various crops during five decades show that cropping pattern in Karnataka is dominated by food crops, with a share of more than 60 per cent of the gross cropped area in the state. Rice, sorghum and finger millet were the major cereals till 2000-03.

- As expected, mixed or inter-cropping is practiced more in the northern and central regions than in the southern region. Rice-rice rotations are common in irrigated areas of southern as well as coastal and hill regions. Sugarcane is grown in sizable areas in all the regions using canal irrigation. Coconut, Malabar nut, grapes, sapota, citrus, etc. are the important fruit crops grown in the state.

The study was conducted in the duration period of $10-15$ days in these 7 regions with 25 crops under different soil condition and climatic conditions. The height of the plants and the leaf size was calculated statistically by taking the mean and average of the plants. The soil used was mostly red dry soil and black soil for the growth and better health. The irrigation method used was $90 \%$ of drip irrigation with minimal force and widespread of water while other $10 \%$ of the crops used sprinkler method.

Use of commercial pests and manure was less compared to the urban region of Karnataka's agricultural lands as in the above-mentioned regions used only cow dung, goat pellets, vegetable waste and organic wastes from their houses. Pesticides, fungicides and bactericides was not used much because $98 \%$, the crops were grown in a better care-taken protection and pest free with no much plant destruction. The crops grown are healthier than the plants grown with commercial ones. These 25 crops show better result of growth, under their favourable conditions. These areas pollution free areas which makes the crops grow healthy and better production for the consumers. The air present in these locations is clear and allows the crops to breathe and live properly.

\section{References}

1. Bailey, W. K., E. H. Toole, V. K. Toole, \& M. E. Drowne. 1958. Influence of temperature on the after-ripening of freshly harvested Virginia bunch peanut seeds. Proc. Amer. Soc. Hort. Sci.71: 422424

2. Karthikeyan G, Doraisamy $S$ and Rabindran $R$ 2009. Induction of systemic resistance in black gram (Vigna mungo) against urdbean leaf crinkle virus by chemicals. Archives of Phytopathology and Plant Protection, 42: 1-15.

3. Nagarjun N and Radder G D 1983. Studies on induction of seed dormancy in bunch type groundnut. Seed Research, 11: 24-31.

4. Patil, V.C. and Shanwad, U.K. (2009). Relevance of Precision Farming to Indian Agriculture. In the Second National Conference on Agrolnformatics and Precision Farming, 2-3 December 2009, Raichur, Karnataka, India.

5. Ravindrababu, B.T., Rajegowda, M.B., Janardhanagowda, N.A. and Girish, J. (2010). Weekly, monthly and seasonal rainfall at Bengaluru in Karnataka. J. Agrometeorol., 12 (2): 263-265.

6. Venkatesh, H., Shivaramu, H.S., Rajegowda, M.B. and Rao, V.U.M. (2016). Agroclimatic atlas of Karnataka, pp 211. 